\title{
透明ポリカーボネート樹脂の曇りに及ぼす電子線照射の 影響について*1
}

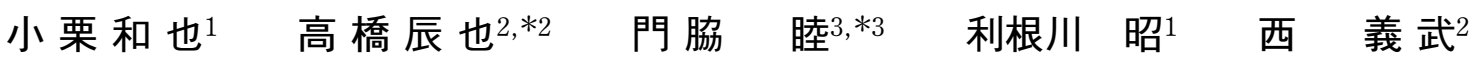

1東海大学理学部物理学科

2 東海大学工学部材料科学科

3 東海大学大学院工学研究科金属材料工学専攻

J. Japan Inst. Metals, Vol. 68, No. 8 (2004), pp. 537-539

(C) 2004 The Japan Institute of Metals

\section{Influences of Electron Beam Irradiation on Misting for Transparent Polycarbonate Resin}

Kazuya Oguri ${ }^{1}$, Tatsuya Takahashi ${ }^{2}{ }^{* 2}$, Atsushi Kadowaki ${ }^{3, * 3}$, Akira Tonegawa ${ }^{1}$ and Yoshitake Nishi2

${ }^{1}$ Department of Physics, Tokai University, Kanagawa 259-1292

${ }^{2}$ Department of Materials Science, Tokai University, Kanagawa 259-1292

${ }^{3}$ Graduate Student of Materials Science, Tokai University, Kanagawa 259-1292

An effect of electron beam irradiation on mist resistance was studied for transparent polycarbonate resin. The electron beam irradiation decreased the time to clear vision on the misted samples. The treatment showed the mist resistance of the resin. To discuss the effect of electron beam on mist resistance, the water wettability, inducated by the surface energy, was evaluated by using contact angle of sessile drop. The electron beam enhanced the surface energy. Based on the heterogeneous nucleation theory, the effects of electron beam on the mist resistance were discussed.

(Received April 28, 2004; Accepted July 5, 2004)

Keywords: electron beam, resin, misting, time to clear vision, surface condition

1. 緒言

近年，量りという現象はさまざまな分野で注目されてい る. 例えば, 空・メガネレンズ・保護面での量りは日常生活 で頻繁に起こっている，曇りの発生は視界を妨げる原因とな ることから，視界不良にともなうさまざまな危険を誘発する 可能性がある. 一方, 低エネルギーの電子線照射処理は一般 にポリマーの重合・架橋に用いられるが, 表面の滅菌処理に も利用できることから, 近年では医療分野での滅菌処理にも 応用が広がっている技術である1). さらに, 炭素繊維・ C/C 複合材料 · CFRP (炭素繊維強化プラスチック)における脆性 改善などの機械的特性の向上も報告されている ${ }^{2-4)}$. 最近で は，透明無機材料に抢ける防曇効果の報告もある5,6). とこ ろで, 空・メガネレンズ・保護面の材料は軽量かつ耐衝撃性 が必要とされることから透明樹脂が用いられる. 特にポリ カーボネートはこれらの特性に優れているため, 多岐にわた って使用されている. そこで本研究では透明樹脂のなかで, 幅広い分野で使用されるポリカーボネート樹脂に, 電子線照 射処理を行い，防量効果の指標となるクリアタイムに及ぼす 影響について検討を行った.

\footnotetext{
*1 2004 年 4 月 1 日日本金属学会春期大会において発表

*2 東海大学学生 (Undergraduate Student, Tokai University)

*3 東海大学大学院生 (Graduate Student, Tokai University)
}

\section{2. 実 験 方 法}

\section{1 電子線照射}

電子線照射処理装置は Fig. 1 に示すエレクトロカーテン プロセッサー(岩崎電気侏 Type CB175/15/180L, 東京)を 用いた.この装置の特徵は, 大気圧下の窒素ガス気流中で, 電子線照射を行える点である. また, 照射処理はコンベア上 でパルス的に電子線を照射することから表面温度の上昇を極

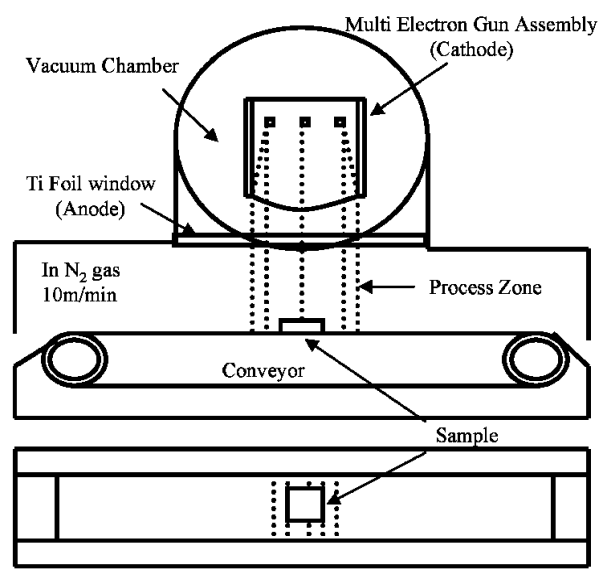

Fig. 1 Schematic diagram of electron curtain processor. 
力抑えることができる. 本研究での電子線照射処理条件は加 速電圧 $170 \mathrm{kV}$ ，照射電流 $2.0 \mathrm{mA，コンベアスピード} 9.56$ $\mathrm{m} / \mathrm{min}$, 電子線照射処理雾囲気は酸素濃度 $400 \mathrm{ppm}$ 以下の 窒素䨌囲気である. また電子線照射線量は照射回数を変化さ せることで制御した。なお，照射線量の校正は RCD ナイロ ン線量計(FWT-60-00 : 線量フィルム, FWT-92D : 吸光度 測定用専用リーダー，FAR WEST TECHNOLOGY，カリ フォルニア)を用いた。 また，電子線照射処理による電子線 の侵入深さ $D_{\mathrm{epth}}(\mu \mathrm{m})$ の算出は式 (1)により行った ${ }^{7)}$.

$$
D_{\text {epth }} \cdot \rho=66.7 V^{5 / 3}
$$

式中の $V$ は加速電圧 $(\mathrm{kV}), \rho$ は密度 $\left(\mathrm{kg} / \mathrm{m}^{3}\right)$ である. 本研 究において, 試料に対する電子線の侵入深さを求める場合, 電子の電子線源から試料に到達するまでの, 電子のエネル ギーロスを考慮する必要がある。電子線通過に伴うエネル ギーロスの原因として Ti 薄板と窒素ガス層通過時の非弾性 散乱によるエネルギーロスがある，本装置の電子線照射空は $\mathrm{Ti}$ 製 $\left(4540 \mathrm{~kg} / \mathrm{m}^{3}\right)$ であり，厚さが $10 \mu \mathrm{m}$ の薄板を使用して いる. また照射空から試料までの距離は約 $30 \mathrm{~mm}$ であり, 照射空から試料間は大気圧の窒素ガス $\left(1.13 \mathrm{~kg} / \mathrm{m}^{3}\right)$ で満た されている。このことから，式（1）を基に試料表面での電 子の平均運動エネルギーを求めると $128 \mathrm{keV}$ となる. 今回 用いたポリカーボネート樹脂の密度 $\rho$ は $1200 \mathrm{~kg} / \mathrm{m}^{3}$ であ る. 試料形状は $15 \mathrm{~mm} \times 15 \mathrm{~mm} \times 2 \mathrm{~mm}\left(15 \times 15 \times 2 \times 10^{-9}\right.$ $\mathrm{m}^{3}$ )である.これらの值から式 (1)を用いて侵入深さを算出 すると, 電子線のポリカーボネート樹脂への侵入深さは $0.185 \mathrm{~mm}\left(1.85 \times 10^{-4} \mathrm{~m}\right)$ となる.

\section{2 量りの評価方法}

曇りの発生は, Fig. 2 に示す曇り評価装置の模式図を示し ている. 試料を $36.0 \pm 0.8^{\circ} \mathrm{C}$ の飽和水蒸気雲囲気中に 3 秒間 曝露し, 行った. 表面に水滴を発生させた後, 室温で曇りの 晴れるまでの時間を計測し，クリアタイムとした。すなわ ち, 恒温室より試料を取り出した時刻を測定開始時刻とし, 曇りの面積が試料表面の $10 \%$ 以下になるまでの時間をクリ

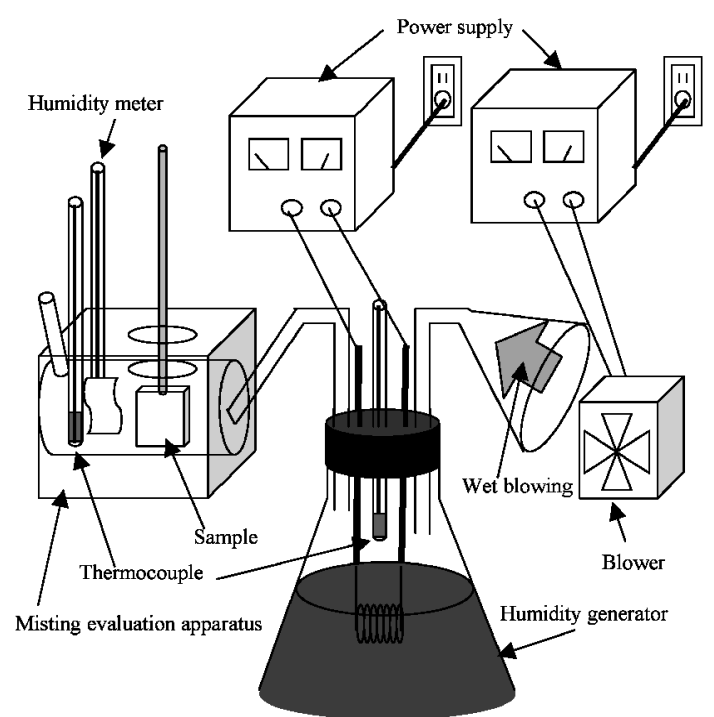

Fig. 2 Schematic diagram of misting evaluation apparatus.
アタイムと定義した。なお，この評価は JIS の S4060-1995 を参考に行っている.

\section{3 ぬれ性の測定·評価方法}

ぬれ性の測定方法には協和界面科学侏製の自動接触角計 $\mathrm{CA}-\mathrm{V}$ を用いた。接触角の測定は大気圧雾囲気で行った。測 定には蒸留水を用い，液滴の水量は $1 \mu \mathrm{L}\left(1.0 \times 10^{-9} \mathrm{~m}^{3}\right)$ と した．なお，電子線照射処理後の接触角の測定は照射後， 5 分経過した時に行った.

固体の表面エネルギー(固体と気体の界面エネルギー) は液 滴の接触角より評価した. 固体と気体の界面エネルギーは式 (2)に示す Young の式8)で表される.

$$
\gamma_{\mathrm{SG}}=\gamma_{\mathrm{SL}}+\gamma_{\mathrm{LG}} \cos \theta
$$

なお， $\gamma_{\mathrm{SG}}$ は固体と気体の界面エネルギー， $\gamma_{\mathrm{SL}}$ は固体と液 体の界面エネルギー， $\gamma_{\mathrm{LG}}$ は気体と液体の界面エネルギー， $\theta$ は接触角である。一方, 界面形成に伴う表面自由エネル ギー変化 $\left(W_{\mathrm{A}}\right)$ は式 $(3)$ に示す Dupré の式で表される.

$$
W_{\mathrm{A}}=\gamma_{\mathrm{SG}}+\gamma_{\mathrm{LG}}-\gamma_{\mathrm{SL}}
$$

この Youngの式, Dupréの式を合成することで YoungDupréの式 $(4)$ が得られる.

$$
W_{\mathrm{A}}=\gamma_{\mathrm{LG}}(1+\cos \theta)
$$

式 (4)より, 液滴の接触角抢よび気体と液体の界面エネル ギー(液体の表面張力)より，固体の大気中での表面自由エネ ルギー変化を算出し評価した.

\section{3. 結 果}

Fig. 3 に電子線照射線量とクリアタイムの関係を示す。こ の図より，電子線照射前のクリアタイムは 10 秒であるが， $0.432 \mathrm{MGy}$ 照射後に 4.5 秒の短時間で量りが晴れる結果を 得た。すなわち，電子線照射処理により，無機材料と同様に クリアタイムが減少し，防曇効果を得られることが分かった。

材料の水に対する好性は，防量効果に大きな影響を与え る可能性が高い。そこで式 (4)より算出した表面自由エネ ルギー変化を水の接触角から求めた. Fig. 4 に電子線照射に 伴う表面自由エネルギー変化を示す。この図より電子線照射

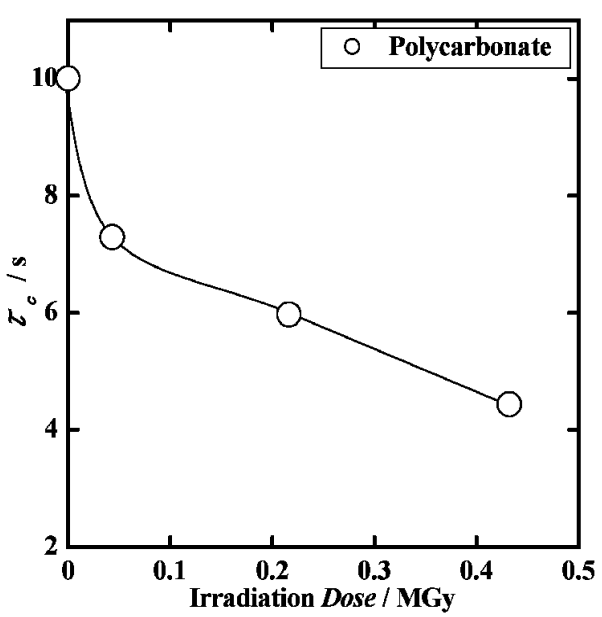

Fig. 3 Change in time to clear vision of polycarbonate resin against electron beam irradiation dose. 


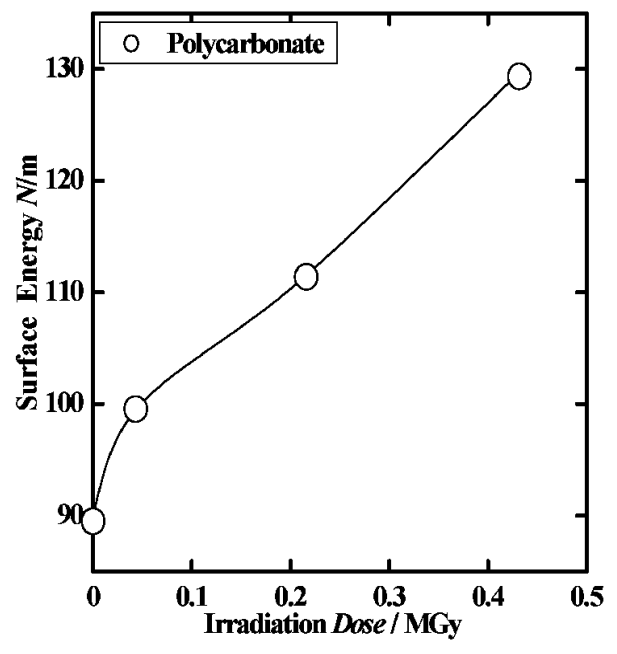

Fig. 4 Change in surface energy against electron beam irradiation dose.

前の表面エネルギーは $90 \mathrm{~N} / \mathrm{m}$ である. 一方, $0.432 \mathrm{MGy}$ 電子線を照射すると $130 \mathrm{~N} / \mathrm{m}$ まで増大することが分かっ た.この結果よりポリカーボネート樹脂の表面は電子線照射 処理によって活性化されるため, ぬれ性が向上することが確 認された. このことにより防量効果が発現すると推定できる.

\section{4. 考察}

量りという現象には, 微小水滴の発生・成長・蒸発の 3 つの段階がある。特に微小水滴の発生段階では, 表面自由工 ネルギーが大きく影響する，表面自由エネルギーが大きいほ ぞ, 核生成のための自由エネルギーが小さく, 臨界曲率半径 は小さくなる. 一方で, クラスター数の時間変化を考慮する と, 表面自由エネルギーが大きくなると, 容易に不均一核発 生を起こしやすくなることが推定できる ${ }^{9)}$.これらのことか
ら, 電子線照射処理により表面自由エネルギーが増加するこ とで，接触角の小さい微小水滴が，多量に短時間で発生する.

さらに, 表面に生成した微小水滴の質量が小さく, 接触角 が小さければ, 短時間で水滴の蒸発が起こり, クリアタイム が減少する.これらのことから, ポリカーボネート樹脂に対 して電子線照射を行うと防量効果が得られたと結論づけるこ とができる。

\section{5. 結 論}

本研究では透明ポリカーボネート樹脂に関して電子線照射 処理を行い，その防曇効果への影響について検討を行った. その結果, 電子線照射処理によって防曇効果の指標となるク リアタイムは減少した。 さらに，これを説明するためにめれ 性の検討を行った. この結果, 電子線照射に伴う表面自由工 ネルギーは増加することが明らかになった，以上の結果よ り,この透明ポリカーボネート樹脂も無機材料と同様に電子 線照射が防量処理の 1 つとなり得る可能性を見出したと結 論付けられる.

\section{文献}

1) A. Kasashima, N. Iwataka, J. Kawano, N. Honda and Y. Nishi: J. Adv. Sci. 67 (1997) 70-71.

2) Y. Nishi, A. Mizutani, A. Kimura, T. Toriyama, K. Oguri and A. Tonegawa: J. Mater. Sci. 38(2003) 89-92.

3) Y. Nishi, N. Uchida, A. Kimura, A. Mizutani, K. Oguri and A. Tonegawa: J. Mater. Sci. 38(2003) 2215-2218.

4) A. Mizutani, N. Motai, K. Oguri, A. Tonegawa and Y. Nishi: J. Japan Inst. Metals 38(2003) 201-204.

5) K. Oguri, N. Iwataka, A. Tonegawa, Y. Hirose, K. Takayama and Y. Nishi: J. Mater. Res. 16 (2001) 553-557.

6) K. Oguri and Y. Nishi: Mater. Trans. 45(2004) 1346-1349.

7) G. Wakalopulos: Radtech Report, July/August (1998) 11-15.

8) T. Young: Trans. R. Soc., London 95 (1805) 65-87.

9) K. Oguri, K. Sato, T. Izumi, A. Tonegawa, K. Takayama and Y. Nishi: Mater. Res. Soc. Symp. Proc. 540(1998) 261-265. 